\title{
Relationship between Breeder Characteristics and Adoption of Artificial Insemination in Bali Cattle
}

\author{
Sitti Nurani Sirajuddin ${ }^{1}$, Indriati Sudirman ${ }^{2}$, Lydia Devega Bahar ${ }^{3}$
}

\begin{abstract}
Artificial Insemination was a program aimed at increasing the production of livestock as well as the income of farmers. The study was conducted from July to September 2017 in Balusu District, Barru District, South Sulawesi Province, Indonesia. The population in this study was the whole Bali cattle breeders who adopt artificial insemination technology located in District Balusu, Barru regency was as much as 548 spread in six villages. With using Slovin formula obtained by the sample amounted to 85 respondents. Kinds of data used in research these were qualitative data and quantitative data. Sources of data used were primary data and secondary data. Methods of data collection were observation and interview. Analyzes used in this research was Rank Spearman. The results showed that closely related to the adoption of IB, namely formal education and temporary business scale associated with the weak of age, family dependents and income.
\end{abstract}

Keywords: adoption, artificial insemination, Bali cattle, characteristics

\section{Introduction}

The problems faced in the field of animal husbandry in Indonesia are still low productivity and genetic quality of cattle. This situation occurs because the majority of farms in Indonesia is still a conventional dairy farmers, where the quality of seed, the use of technology and skills are still relatively low breeders. Artificial insemination is the alternative technologies that are being developed in an effort to increase the productivity of local cattle biologik Indonesia through breeding technology which results relatively quickly and was satisfactory and has expanded implemented is the cattle livestock took a superior import (Hastuti, 2008). The implementation of the activities of artificial insemination (IB) is one of the efforts the application of appropriate technology and its success is influenced by five factors namely (i) the quality of frozen semen breeders level, (ii) knowledge and caring breeder in doing detection of lust (iii) body condition score of beef cattle health (iv) and (v) the skills and the attitude of the inseminator (BIB,2011; Dwiyanto,2012; Caraviello et al 2006) so one factor that affect IE breeders. The human factor is a very important factor in the success of the IB program because it has a central role in the activities of the IB services. The human factor, the means and the conditions of the field is a very dominant factor. Inseminator and the breeder is spearheading the implementation of the IB at once as the party responsible for the successful or whether the IB program in the field (Hastuti et al, 2008).

$\mid{ }^{1}$ Department of SocialEconomic, Faculty of AnimalHusbandry, Hasanuddin University, Perintis Kemerdekaan Street Km. 10, Tamalanrea Indah, Tamalanrea, Makassar 90245, South Sulawesi, Indonesia

2Department of Management, Faculty of Economics and Business, Hasanuddin University, Perintis Kemerdekaan Street Km. 10, Tamalanrea Indah, Tamalanrea, Makassar 90245, South Sulawesi, Indonesia

${ }^{3}$ Agribusiness Study Graduate Program, Hasanuddin University, Perintis Kemerdekaan Street Km. 10, Tamalanrea Indah, Tamalanrea, Makassar 90245, South Sulawesi, Indonesia 


\section{Research Methods}

The research was carried out in July - September 2017 in Barru Regency Balusu Subdistrict, South Sulawesi. This research is a survey research in the form of observational methods are purely cross-sectional approach, namely a study done with observation a moment or in a given time period and any subject of study It is only done once observations during research (Machfoedz, 2007). The population in this research is the entire Bali cattle farmers who adopt the technology of artificial insemination that reside in district Balusu IE as much as 548 scattered in six subdistricts/villages. By using the sample Slovin formula obtained amounted to 85 people respondents. Types of data used in this research is qualitative data and quantitative data. The source of the data used, namely primary data and secondary data. Method of data collection i.e., observation and interview. Analytical tools used in this research is the Rank Spearman.

\section{Results and Discussion}

\subsection{Adoption Artificial Insemination}

Adoption is a process that occurred since the first time someone hears something new for the person to adopt (accept, implement, use) new things. In the process of adoption, targeted farmers take a decision after going through several stages. At first, an innovation targeted farmers know, that could be something really new or that has long been found but is still new to the targeted farmers. If the targeted farmers apply an innovation, then the targeted farmers abandon the old ways (Abraham, et al., 2003).

Adoption is a decision to use a completely new idea as a way of acting is the best. Innovation is a process of mental decisions, since a person is aware of any innovations to take the decisionto accept or reject it and then tighten it. The decision of innovation is a type of decision making that is typical (Suprapto and Fahrianoor, 2004).

For the adoption of artificial insemination in Barru Regency of Bali cattle needed and already applied by cattle farmers. For details of attribute the adoption of artificial insemination can be seen in Table 1

Table 1. Attributes of the Artificial Insemination Technology Adoption

\begin{tabular}{|c|c|c|c|}
\hline No & Category & Total (Person) & Percentage $(\%)$ \\
\hline \multirow{5}{*}{1} & Number of Cows in IB & & \\
\hline & 1 & 58 & 68,2 \\
\hline & 2 & 21 & 24,7 \\
\hline & 3 & 5 & 5,9 \\
\hline & 4 & 1 & 1,2 \\
\hline \multirow{4}{*}{2} & Applying Breeders year IB & & \\
\hline & $1996-2002$ & 3 & 3,5 \\
\hline & $2003-2009$ & 2 & 2,3 \\
\hline & $2010-2017$ & 80 & 94,2 \\
\hline \multirow{3}{*}{3} & IB has been appropriately applied in Barru & & \\
\hline & Yes & 7 & 8,2 \\
\hline & No & 78 & 91,8 \\
\hline
\end{tabular}




\begin{tabular}{clcc}
\hline No & Category & Total (Person) & Percentage (\%) \\
\hline \multirow{2}{*}{4} & IB is a necessity in Barru & & \\
& Yes & 80 & 94,1 \\
& No & 5 & 5,9 \\
\hline \multirow{2}{*}{$\mathbf{5}$} & IB better than Natural Mating & & \\
& Yes & 59 & 69,4 \\
& No & 26 & 30,6 \\
\hline
\end{tabular}

Source: Primary Data Once processed, 2017

Table 1 shows the breeder just doing the IB on one cow them for an average of 1-11 livestock ownership tail consisting of the parent, male, virgin and calf. So who can in IB only 1 or 2 heads just because some parent is mated naturally. Most farmers begin to perform artificial insemination in cows in 2010 to 2017. However, there are three farmers who had long been implementing IB which began in 1996.

According right breeder IB already applied in Barru because it is a necessity. Artificial insemination has become a necessity because based on the fact that there bulls have been hard to find. The bulls are focused in fattening.

\subsection{Factors Related to the characteristics breeders Adoption Artificial Insemination}

\subsubsection{Age}

Age is one indicator that shows the person's physical abilities. People who have an older age physically weaker than the person who is younger. Age a breeder can influence their work productivity in the farm business activities. Age is also closely related to the mindset of farmers in determining management system which will be applied in business activities peternakan.Klasifikasi respondent's age can be seen in Table 2

Table 2. Classification of Respondents based on Age in district Balusu

\begin{tabular}{cccc}
\hline No. & Age (years) & Total (person) & Percentage (\%) \\
\hline $\mathbf{1}$ & $0-14$ & 0 & 0 \\
$\mathbf{2}$ & $15-64$ & 64 & 87,9 \\
$\mathbf{3}$ & $\geq 65$ & 11 & 12,1 \\
\hline & Amount & 85 & 100 \\
\hline
\end{tabular}

Source: Bahar, 2017.

Classification of respondents based on age showed that $87.9 \%$ of respondents who adopted the IB technology in Bali cattle in the district belong to the productive age Balusu Barru which have a range of ages between 15-64 years. The condition suggests that the relatively prolific breeders in the sense of physical well ability so that it can leverage in developing a farm business. In accordance with the opinion of Swastha (1997) in Saediman (2011) that a person work productivity will increase in accordance with increasing age, then decline back towards old age. Wahid, S., (2012) adds that the aging of the population is grouped into three: (1) age 0-14 years is called young / age has not been productive, (2) age 15-64 years of age called adult / working age / child bearing 
age, and (3) age 65 years or older is called aging / age unproductive / age also fits the opinion jompo. Nurlina (2007) in Herath et al (2012), age and educational background breeder affect one's ability to accept something new or adopt innovations. For farmers aged 25-40 years parameters usually adopter early, early adopter age 41-45, age 46-50 years adopter end and more than 50 years may be a repellent group

\subsubsection{Education}

In animal husbandry education factor expected to help people in an effort to increase production and productivity of livestock being kept. Adequate education level will have an impact on improving the performance and management capabilities run farm. Classification of respondents by level of education in the District Balusu Barru can be seen in Table 3 .

Table 3. Classification of Respondents According to Education.

\begin{tabular}{clcc}
\hline No. & Level of education & Total (person) & Percentage (\%) \\
\hline $\mathbf{1}$ & No school & 6 & 7,1 \\
$\mathbf{2}$ & elementary school & 51 & 60 \\
$\mathbf{3}$ & junior high school & 14 & 16,5 \\
$\mathbf{4}$ & senior High School & 11 & 12,9 \\
$\mathbf{5}$ & Diploma 3 & 1 & 1,2 \\
$\mathbf{6}$ & graduate & 2 & 2,3 \\
\hline & Amount & 85 & 100 \\
\hline
\end{tabular}

Source: Bahar, 2017

Table 3 shows the education level of respondents in District Barru Balusu ie at the elementary level at most that SD with the number $51(60 \%)$ and the lowest is the level of D3 is 1 person $(1.2 \%)$. This indicates that the level of education of farmers who do not adopt the IB technology in Bali cattle is still very low. This will affect the mindset of decision making financing of the business. This condition suggests that one of the reference person in decision-making is where the higher education level of one's education level it will be bold in the decision making. This is in accordance with the opinion Reksowardoyo (1983) that the education will increase knowledge, develop attitudes and foster the interests of farmers, especially in the face of change.

\subsubsection{Livestock Ownership}

Owners of livestock indicates the number of Bali cattle were maintained and owned by the breeder.To see the number of Bali cattle holdings which did IB can be seen in Table 4.

Table 4. Cattle Classification Based on Total Ownership Bali Bali Cattle

\begin{tabular}{cccc}
\hline No & Owners Livestock (Tail) & Total (person) & Percentage (\%) \\
\hline $\mathbf{1}$ & $1-11$ & 76 & 89,4 \\
$\mathbf{2}$ & $12-21$ & 7 & 8,3 \\
$\mathbf{3}$ & $22-32$ & 2 & 2,3 \\
\hline & Amount & 85 & 100
\end{tabular}

Source: Bahar, 2017 
In Table 4 shows that the ownership of cattle Bali in Bali cattle ranchers who do not adopt the technology IB Balusu Bali cattle in the district indicate that livestock ownership highest in 1-7 tail with the number of farmers is 76 people with a percentage of $89.4 \%$. Farmers who do not adopt these technologies have a number of animals a little. If seen from the number of animals in each breeder can be classified in the farms. This is in accordance with the opinion Fadilah et al., (2007) found that farm business group with the number of small-scale livestock also called farms.

\subsubsection{Income Level}

Income or income is all income earned by the family in the form of money or services. According to the statistics Central Agency (BPS) in 2008 revenue is classified into four, namely:

a. Very high income brackets ( $>$ IDR 3,500,000 per month)

b. High income groups (IDR 2,500,000 - IDR 3,500,000 per month)

c. Medium income brackets (IDR 1,500,000 - IDR 2,500,000 per month)

d. Lower income brackets ( $<$ IDR 1,500,000)

According to Fatah, the economic capacity of rural communities will determine the level of participation in development (2006). Therefore we can conclude the public with a high level of economic capacity, high participation. While people with a low level of economic capacity is also low participation, because they will vote for. Earn a living so that his participation was lacking. Based on the income level, most of the respondents belong to the farmers who can afford it, this can be seen in Table 5

Table 5. Distribution of farmers who adopt IB Technology According Income Level

\begin{tabular}{|c|c|c|c|}
\hline No & Income Level (IDR/ month) & Total (person) & Percentage $(\%)$ \\
\hline 1 & $\leq 1.000 .000$ & 8 & 9,4 \\
\hline 2 & $2.000 .000-5.000 .000$ & 62 & 72,9 \\
\hline 3 & $6.000 .000-10.000 .000$ & 13 & 15,3 \\
\hline 4 & $11.000 .000-15.000 .000$ & 1 & 1,2 \\
\hline \multirow[t]{2}{*}{5} & $\geq 15.000 .000$ & 1 & 1,2 \\
\hline & Amount & 85 & 100 \\
\hline
\end{tabular}

Source: Primary Data Once processed, 2017.

Table 5 shows that the farmer's adopted income is highest in the range of IDR.2.000.000- IDR.5.000.000, this indicates that the breeder is on the medium scale upwards, this is in accordance with the classification of BPS (2008) that the interval> IDR 3,500,000 is very high income brackets, IDR 2,500,000 - IDR 3,500,000 per month is high income groups and IDR 1,500,000 - IDR 2,500,000 per month is medium income brackets

\subsubsection{Number of Family Members}

The number of family members contributes substantially to the livestock business because the main source of labor is active and productive family labor. Conversely, the large number of family dependents, but not contributing positively to livestock business will be a burden for the livestock business (Rahmah, 2014). The number of family members of farmers who adopt IB can be seen in Table 6 
Table 6. Number of Family Members Balusu Respondents in the district, Barru

\begin{tabular}{cccc}
\hline No & Number of Family Members & Total (person) & Percentage (\%) \\
\hline $\mathbf{1}$ & $1-2$ & 61 & 71,8 \\
$\mathbf{2}$ & $3-4$ & 22 & 25,9 \\
$\mathbf{3}$ & $<4$ & 2 & 2,3 \\
\hline & Amount & 85 & 100 \\
\hline
\end{tabular}

Source: Results of Primary Data Processed

For the number of family members indicates the number of 3-4 persons is the highest number $(47.7 \%)$. The number of family members influences in managing a business, in line with Sobait et al (2011) opinion that the number of family members of a rancher can affect the business activity of the farmer because the number of family members can supply the availability of labor that can assist his activities and if the larger number of family members the greater the family needs that must be met

\subsection{Characteristic Factors Associated with Artificial Insemination Adoption}

To determine the relationship between factors: age, formal education, knowledge of IB, business scale, income and number of family members with adoption of artificial insemination can be seen in Table 7 .

Table 7. Factors Related to Artificial Insemination Adoption

\begin{tabular}{|l|c|c|c|}
\hline \multirow{2}{*}{ Factors Characteristic } & \multicolumn{3}{|c|}{ coefficient of relation Rank Spearman } \\
\cline { 2 - 4 } & \multicolumn{2}{|c|}{ Adoption of artificial insemination } \\
\cline { 2 - 4 } & $\begin{array}{c}\text { Value Korelasi } \\
\text { Rank Spearman(rs) }\end{array}$ & Sig & $\begin{array}{c}\text { relationship level } \\
\text { interpretation (Gullford) }\end{array}$ \\
\hline Age & $-0,025$ & 0,818 & Very weak \\
\hline Education & $-0,227$ & 0,037 & weak \\
\hline Knowledge about artificial insemination & $-0,033$ & 0,768 & Very weak \\
\hline Scale enterprises & $-0,054$ & 0,626 & Very weak \\
\hline income & $-0,087$ & 0,427 & Very weak \\
\hline Dependent of family & 0,005 & 0,961 & Very weak \\
\hline
\end{tabular}

Table 7 shows that:

1. The relationship between the age level with the adoption rate is very weak category and the direction of the relationship is inversely related if the variable $\mathrm{X}$ is high then the low $\mathrm{Y}$ variable is indicated by the value of negative and the relationship is not significant 2. The relationship between formal educations with the adoption rate is in the weak but definite category and the direction of the relationship is inversely related to the weak but definite variable relationship and significant relationship

3. The relationship between knowledge about IB and adoption rate is very weak category and the direction of the relationship is inversely related if the variable $\mathrm{X}$ is high then the low $\mathrm{Y}$ variable is indicated by the negative value and the relationship is not significant 4. The relationship between the scale of business and the level of adoption is in the category of very weak and the direction of the relationship inversely proportional means if the variable $\mathrm{X}$ high then low $\mathrm{Y}$ variable that is marked with a negative value and the relationship is not significant 
5. The relationship between income and adoption rate is in very weak category and the direction of the relationship is inversely related if the variable $\mathrm{X}$ is high then the low $\mathrm{Y}$ variable is indicated by the negative value and the relationship is not significant

6. The relationship between the number of family members and the adoption rate is in very weak category and the direction of the relationship is inversely related if the variable $\mathrm{X}$ is high then the low $\mathrm{Y}$ variable is indicated by the negative value and the relationship is not significant

\section{Conclusions}

Characteristics of breeders is associated with the weak adoption of IB in Barru district so it is necessary to do intensive extension activities so that knowledge about the benefits of IB can be known by beef cattle farmers.

\section{References}

Asghar B, R S Marzieh. 2011. Factors affecting Adoption of Artificial Insemination in Dairy Farms of Ardabil Province (a comparison of models). Iranian Journal of agricultural economics and development research.42(2):287-300

Badriyah N dan R Setiawan.2012. Hubungan Pengetahuan Peternak Sapi Potong Terhadap Keberhasilan IB di Kecamatan Sarirejo Kabupaten Lamongan.Jurnal Ternak 3(2) :10-18

Balai Inseminasi Buatan (BIB). 2011. Buku Pintar Inseminasi Buatan. Balai Inseminasi Buatan, Lembang.Direktorat Jenderal Peternakan dan Kesehatan Hewan, Kementerian Pertanian

Bayey J D and A I Nache.2014. The Effect of Socio-Economic Characteristics of Cattle Farmers on The Adoption of Artificial Insemination Technology in Kaduna State of Nigeria. IOSR Journal of Agriculture and Veternary Science.7(9) 11-17

Caraviello,D.Z.K.A.weigel,P.M.Fricke,M.C.Wiltbank,M.J.Florent,N.B.Cook,K.V.Nordlund,N.R Zwald and C.L.Rawson.2006. Survey of Management Practices on Reproductive Performanceof Dairy Cattle on Large us Commercial Farms. Department of Dairy Science, University of Wilconsin, Madison 53706. School of Veterinary Medicine, University of Wisconsin, Madison. Journal of Dairy Science.89(12):4723-4735

Diwyanto,K. 2012. Optimalisasi Teknologi Inseminasi Buatan Untuk Mendukung Usaha Agribisnis Sapi Perah dan Sapi Potong. Bunga Rampai.Puslitbangnak

H M Salim,M a Halim,N Akter and M H Rashid. 2004. Evaluation of Adoption Status of Artificila Insemination Techninique on dairy cattle at Farmers level. Pakistan Journal of Biological Sciences. $7(5): 674-678$

Hastuti,D. 2008. Tingkat Keberhasilan Inseminasi Buatan Sapi Potong Ditinjau dari Angka Konsepsi dan Service Per Conception. Mediagro.4(1):12-20

Herawati T.A Angraeni.L Praharani, D Utami.A Argiris. 2012. Peran Inseminator dalam keberhasilan Inseminasi Buatan pada sapi Perah. Informatika Pertanian. 21(2) :81-88

Howley P,C O Donoghue,K Heanue. 2012. Factors Affecting Farmers Adoption of Agricultural Innovations : A panel data analyisis of the use of artficila Insemination among dairy afrmers in Ireland. Journal of Agricultural Science :4(6):171-179

Labetubun J,F.Parera,S.Saiya.2014. Evaluasi Pelaksanaan Inxeminasi Buatan pada Sapi Bali di Kabupaten Halmahera Utara. Agrinimal.4(1):22-27

Melessa A,J Jemal and A malesse. 2013. Factors affecting the level of adoption of dairy technologies in Ada'a and Lume Distrcits, East Shoa-Ethiopia. Agricultural Science Research Journals.3(8) :237-243

Murwanto A G.2008. Karakteristik Peternak dan Tingkat Masukan Teknologi Peternakan Sapi Potong di Lembah Prafi Kabupaten Manokwari. Jurnal Ilmu Peternakan. 3(1):8-15 
Prokopy,L.S.,Floress.K.,Klotthor-Weinkauf,\&Baumgarts-Getz.2008. Determinants of agricultural best management practice adoption:Evidence from the literature.Journal of Soil and Water Conservatioan.63(5):300-311

Rathod P,M Chander \&Chetan S G.2017. Adoption status of artificial insemination in indian dairy sector application of multinomial logit model. Journal of Applied Research.45(1):442-446

Tefera S S,J K Lagat \& H K Bett. 2014. Determinants of Artificial Insemination use by smallholder dairy Farmers in Lemu-Bilbilo District,Ethiopia.International Journal of African and Asian Studies. Vol 4.pp 91-98

Tophianong T.C,Agung B,Erif M N. 2014. Tinjauan Hasil Inseminasi Buatan Berdasarkan Anetrus Pasca Inseminasi pada Peternakan Rakyat Sapi Bali di Kabupaten Sikka Nusa Tenggara Timur. Jurnal Sain Veteriner.32(1): 46-54

Umam K,N.Kusrini,D Kurniati.2012. Hubungan Antara Karakteristik dengan Persepsi Peternak Terhadap Inseminasi Buatan pada Sapi Potong Kelurahan Tuan-Tua Kecamatan Benua Kayong Kabupaten Ketapang.Jurnal Sosial Ekonomi Pertanian. 1(3):23-28 